\title{
Realist cinema as world cinema
}

Book or Report Section

Accepted Version

Nagib, L. (2017) Realist cinema as world cinema. In: Stone, R. and Cooke, P. (eds.) The Routledge Companion to World Cinema. Routledge, Abingdon-on-Thames, pp. 310-322. ISBN 9781138918801 Available at http://centaur.reading.ac.uk/69372/

It is advisable to refer to the publisher's version if you intend to cite from the work. See Guidance on citing.

Publisher: Routledge

All outputs in CentAUR are protected by Intellectual Property Rights law, including copyright law. Copyright and IPR is retained by the creators or other copyright holders. Terms and conditions for use of this material are defined in the End User Agreement.

www.reading.ac.uk/centaur 


\section{CentAUR}

Central Archive at the University of Reading

Reading's research outputs online 


\title{
REALIST CINEMA AS WORLD CINEMA
}

\author{
Lúcia Nagib
}

The idea that "realism" is the common denominator across the vast range of productions normally labelled as "world cinema" is widespread and seemly uncontroversial. Thus, it is not surprising that Thomas Elsaesser should start his insightful essay on "World Cinema: Realism, Evidence, Presence" by declaring: "European art/auteur cinema (and by extension, world cinema) has always defined itself against Hollywood on the basis of its greater realism" (2009: 3). It is easy to infer the whole story behind this formula: world cinema started in Europe, more precisely with Italian neorealism in the 1940s, which, on the basis of a documentary approach to the real, offered fertile ground for the development of art and auteur cinema. Turning its back on Hollywood fantasy and standing on the grave of the Nazifascist propaganda machine, this new realist cinema unveiled on screen the gritty reality of a poverty-stricken, devastated Europe in the aftermath of the Second World War. As we know, the raw aesthetics and revelatory power of this foundational movement inspired a flurry of subsequent (social-)realist schools in the world, such as Indian independent cinema in the 1950s, Brazilian Cinema Novo in the 1960s, African post-independence cinemas in the 1970s, the New Iranian Cinema in the 1980s, Danish Dogme 95 in the 1990s and many other new waves and new cinemas, remaining influential up to today. Neorealism was moreover the touchstone of André Bazin's concept of cinematic realism, the world's most revolutionary and enduring film theory ever written, albeit in the form of short magazine articles. As is well known, the film medium, for Bazin (1967), is intrinsically realist thanks to the "ontology of the photographic image," that is, the medium's recording property which establishes a material bond with its referent in the objective world, a process later equated by Peter Wollen 
(1998: 86) to “indexicality" as defined by Charles Sanders Pierce's semiotic theory. Bazin was moreover, and most importantly to my own approach, the first to locate realism at the point of production, by extolling, about neorealism (Rossellini, Visconti, De Sica), the regular use of real locations, non-professional actors (as well as actors stripped of their acting personas) and the combination of long takes and long shots that preserve the space-time integrity of the profilmic event.

But Elsaesser's synthetic formula also contains some incendiary material. Should we take for granted that Europe is the centre of world cinema and that theory about it must consequently be Eurocentric, or at least Europe-centred? Does all world cinema depend on its artistic and auteurist pedigree? And is world cinema forever condemned to be the other of Hollywood - or Bollywood, or Nollywood, or any popular cinema? These questions were at the heart of world cinema theorizing at the beginning of the new millennium, as an increasingly globalized world made it imperative to look at different cinemas through their transnational relations. I too have attempted to define world cinema positively, as a set of active expressions of local histories and cultures, rather than mere reactions against commercially and/or ideologically hegemonic cinemas (see Nagib 2006; Nagib et al. 2012). In this chapter, however, I shall propose to leave the Euro- and Hollywood-centric as well as the art/auteur vs commercial dilemma behind and move a step further by replacing the rather vague, and often unhelpful, "world cinema" appellation with the more substantive "realist cinema," which is defined by an ethics of the real that has bound world films together across history and geography at cinema's most creative peaks.

In order to do so, it is first necessary to ask: where does realism actually lie? Why is it so easy to define as "realist" a film such as Boyhood (2014), made at the gravitational centre of mainstream cinema, the United States, by Richard Linklater who Rob Stone (20015: 67) refers to as "one of the most important filmmakers in world cinema?" It is certainly not for its 
reasonably conventional "illusionist" mode of storytelling, nor its relative commercial success, and not at all for any overwhelming sensory experience it might afford the spectator, but most certainly for its realist mode of production, that is, because the film crew went through the trouble of spending 12 years filming a boy as he grew up from 6 to 18 years of age so as to achieve a complete fusion between the actor and the character. As much as the Deleuzian time-image and the sensory-motor relation it establishes with the spectator have become the all-time champions of world-cinema theorizing, not least thanks to the rise of what became known as "slow cinema," it is now time to turn the gaze to how these images and sounds are produced and captured, and the tremendous effort a number of film crews and casts from all over the world put into producing as well as reproducing reality. It is necessary to ask: why did a filmmaker such as Joshua Oppenheimer need to remain for eight years in close contact with utterly dangerous and powerful criminals in Indonesia, and to learn Indonesian in the process, in order to make The Act of Killing (2012), an instant landmark in documentary-making? Why do some filmmakers have their cast perform real sex for the camera, as in Nagisa Oshima's erotic masterpiece The Real of the Senses (Ai no koriida, 1976), when others are perfectly happy with simulating it? Why does Werner Herzog have to travel to the remotest corners of the world, exposing his cast and crew to the rigours and perils of the Amazon jungle or the Sahara Desert when he could stage these acts in a studio?

In order to address these questions, this chapter will veer away from the recent trend of focusing on the materiality of the spectatorial body and the sensuous reception of films, locating instead cinematic realism in the way films are made. I will argue that film crews and casts who choose to produce rather than just reproduce reality and to commit themselves to unpredictable events are moved by an ethics that Alain Badiou has defined as "an active fidelity to the event of truth" (2006: xiii; see also Nagib 2011: 1ff in this respect). Three facts speak in favour of this model. First, realism at the point of production is clearly identifiable 
and measurable, as opposed to the "reality effect" at the point of reception, which varies widely from one individual to another, remaining inevitably restricted to the speculative realm. Second, realism can be achieved at the point of production regardless of the technology utilized for the capturing of images and sounds, whether it is the now obsolete celluloid strip or digital equipment. And third, realism is timeless, as the recurrent emergence of realist trends at certain historical junctures demonstrates, and is consequently not the result of the "evolution of the language of cinema" or tributary to a supposed postwar modernity, as Bazin (1967b) would have had it.

In order to substantiate these contentions, I will start, unavoidably, by revisiting Bazin's realist theory, as well as its recent revival, defined by Elsaesser (2009: 11) as “ontology mark two." I will then proceed to laying out a possible taxonomy of cinematic realism according to modes of production, address, exhibition and reception. This will be followed by a look at sub-modalities of the realist mode of production in the light of representative film examples, from the negation of cinema that changes it into a way of living and interfering politically with the world phenomena; to the intermedial procedure that turns other art forms within films into a channel to the real; and finally to the utopian "myth of total cinema" which Bazin defined as the human desire for "integral realism."

\section{Reality Between Modernity and the Digital Age}

Bazin is central to this chapter because most of what he said about realism in the late 1940s and 1950s would apply to what is understood under "world cinema" nowadays. This being a term originated in the Anglophone world, untranslatable in most other film cultures and 
unavailable in Bazin's time, he chose to give to the new realism of his time the name of "modern cinema."

As I have discussed at length elsewhere (Nagib 2016: 25ff), this choice was coherent insofar as it represented the culmination of Bazin's evolutionist approach, according to which the best films ever made could not but be located in his own time. "Modern cinema" thus starts with Italian neorealism in the late 1940s, excluding from its ranks not only what Bazin (1967b) calls the "classical" Hollywood cinema, but prewar modernist cinema itself, as represented by Eisenstein and Soviet cinema, German Expressionism and the European avant-gardes in general, due to their allegiance to montage. Though circumstantial and transient at origin, the concept of "modern cinema" has prevailed in film studies ever since, having been lavishly applied to signify almost any narrative films produced outside the Hollywood system from the Second World War onwards. However, beyond the questionable opposition between modernity and modernism, this model is further flawed by the fact that many realist filmmakers of Bazin's own pantheon, including Renoir, Stroheim, Murnau and Dreyer, were active much before the Second World War and already resorting to the techniques he deemed both realist and modern. Conversely, neorealist filmmakers were not necessarily averse to montage, if you just think of the quick-fire editing in Rossellini's Germany Year Zero (Germania anno zero, 1947), a neorealist milestone which is more akin to the urban velocity featured in a modernist film like Berlin: Symphony of a Great City (Berlin: die Symfonie der Grosstadt, Walter Ruttmann, 1927) than to the contemplative attitude associated with the Bergsonian durée at the base of Bazin's definition of modern cinema. These contradictions have not stopped Bazin's evolutionist model from continuing to be widely adopted in film scholarship, not least thanks to the endorsement it received from Deleuze (2013), the most influential film philosopher of all time, who adopted the Second World War as the dividing line between classical and modern cinema, these being 
respectively characterized by the "movement-image" and the "time-image," which disregard chronology even more frontally than Bazin.

Whilst paying due respect to these seminal theories, my proposal is to think about realism and world cinema away from evolutionist models that fail to cohere even with the schemes in which they originated, and which inevitably place Europe as the gravitational centre of world/modern cinema and in irrevocable opposition to Hollywood and all other socalled classical/commercial cinemas. As David Martin-Jones (2011: 7) rightly suggests, keeping away from Eurocentric and "othering" mechanisms can reinvigorate these thinkers' ideas and broaden their scope for future usage. Thinking in terms of modes of production would do precisely that without excluding works pre- or post-WWII, along the lines, for example, of Siegfried Kracauer, whose famous book Theory of Film: The Redemption of Physical Reality describes cinema as dominated from the outset by "realistic" and “formative" tendencies, represented respectively by Lumière's documentaries and Méliès' fantasy films (1997: 30ff).

My proposal of a timeless view of realism has nonetheless to overcome a serious historical hurdle which is the advent of digital technology. Both Bazin and Kracauer were theorizing on the basis of photographic recording, or, in Bazin's terms, the "ontology of the photographic image," through which the object is directly imprinted on the film emulsion without the mediation of the human being, as in the case of the death mask or the Holly Shroud (Bazin, 1967: 14). However, digital technology changed the process of recording in radical ways that disrupted film's fundamental link with the objective real, as Miriam Hansen was quick to note in her introduction to the 1997 edition of Kracauer's book (viii):

Digital technologies such as computer enhancement, imaging, and editing have shifted the balance increasingly toward the postproduction phase. Not only can 
"mistakes" made during shooting be "corrected" and recorded effects be maximized, but on the very level of production live-action images and sounds can be generated independently of any referent in the outside world.

This argument was later expanded upon by new-media herald Lev Manovich, who observes:

Cinema traditionally involved arranging physical reality to be filmed through the use of sets, models, art direction, cinematography, etc. Occasional manipulation of recorded film (for instance, through optical printing) was negligible compared to the extensive manipulation of reality in front of a camera. In digital filmmaking, shot footage is no longer the final point but just raw material to be manipulated in a computer where the real construction of a scene will take place. In short, the production becomes just the first stage of post-production. (2016: 29)

Perfectly valid in principle, this argument however obscures the fact that many filmmakers continue to valorize production above post-production, even when using digital technology. Indeed, one of the most remarkable consequences of the digital revolution was to enable filmmakers from the most disparate areas of the globe to embark in otherwise unthinkable realist ventures. An example is the first Inuit feature-length film ever made, Atanarjuat, the Fast Runner (Zacharias Kunuk, 2001), which could only come to life thanks to the lightweight, versatile digital equipment that allowed for shooting in sub-zero temperatures and in remote areas of the Arctic circle inaccessible to motor vehicles. No tricks and effects added in post-production could ever efface the indexical power of this film, in which, for the first time, 
an entirely Inuit cast re-enacts their mythology in their own territory, language and costumes, climaxing with actor Natar Ungalaak running stark naked and barefoot on the glacial landscape during more than seven minutes of edited stock. Probably because the evidentiary power of digital filming could be brought into question, some footage from the filmmaking process was added to the final credits, in which we see Ungalaak being followed by the camera mounted on a sledge pushed by other crew members, and later wrapped in a blanket to keep warm between shots.

Having sparked an avalanche of scholarship and ushered in a "post-cinematic" era, as announced in the excellent newly-launched collection Post-Cinema: Theorizing $21^{\text {st }}$ Century Film (2016), the digital revolution is also at the core of Elsaesser's aforementioned essay, which defines realism in the post-photographic era as an "ontology mark two." Unconcerned with the loss of the index and brought about by computer-generated images and sounds, this new ontology, for him, "breaks with the Cartesian subject-object split, abandoning or redefining notions of subjectivity, consciousness, identity and the way these have hitherto been used and understood" (2009: 7). It is however intriguing that Elsaesser should produce evidence to his thesis through the analysis of a film such Three Iron (Bin jip, Kim Ki-duk, 2004). Granted, in this film, humans share agency with objects and spaces, the animate and inanimate swap roles, and characters become visible and invisible at will. The real and its representation are thus brought into question, but only as mode of address, that is, as fictional subjects in a plot akin to postmodernism and the horror genre. As a result, "ontology mark two" avers itself as a mere exercise in style.

Whatever the case, Elsaesser's film example is useful as it highlights the blind spot still in need to be clarified: the phases and modes in which cinematic realism may (or may not) be produced. In order to clarify this point, I will now proceed to laying out a tentative 
taxonomy of cinematic realism covering the film process in its various phases, from production to reception.

\section{Towards a Possible Taxonomy of Cinematic Realism}

Bearing in mind the limitations and artificiality of all schemes, and that the modes below never come isolatedly, but are entwined and mutually dependent, I will attempt to establish the possible locations of realism in cinema as follows:

\begin{tabular}{|l|l|l|l|}
\hline \multicolumn{5}{|c|}{ TAXONOMY OF CINEMATIC REALISM } \\
\hline Modes of Production & Modes of Address & Modes of Exhibition & Modes of Reception \\
\hline $\begin{array}{l}\text { Physical engagement } \\
\text { on the part of crew and } \\
\text { cast with the profilmic } \\
\text { event }\end{array}$ & $\begin{array}{l}\text { Narrative realism as } \\
\text { obtained by the } \\
\text { "cinematographic } \\
\text { apparatus" }\end{array}$ & $\begin{array}{l}\text { Films that include live } \\
\text { performance, such as } \\
\text { in expanded cinema } \\
\text { experiments }\end{array}$ & $\begin{array}{l}\text { Audiences' and } \\
\text { market behaviour }\end{array}$ \\
\hline $\begin{array}{l}\text { Identity between casts } \\
\text { and their roles }\end{array}$ & $\begin{array}{l}\text { The production of an } \\
\text { "illusion of reality" }\end{array}$ & $\begin{array}{l}\text { Or the opposite, films } \\
\text { aiming at extreme } \\
\text { illusionism: 3D and } \\
\text { Imax environments, } \\
\text { and 4D Virtual Reality } \\
\text { works }\end{array}$ & $\begin{array}{l}\text { The way films affect } \\
\text { the "mind" or "mental } \\
\text { structures" }\end{array}$ \\
\hline Real location shooting & $\begin{array}{l}\text { The "reality effect" } \\
\text { derived from graphic } \\
\text { or sensational } \\
\text { representations }\end{array}$ & $\begin{array}{l}\text { Realism as affect } \\
\text { involving the body and } \\
\text { the senses }\end{array}$ \\
\hline Emphasis on the index & & $\begin{array}{l}\text { Interactive behaviours } \\
\text { as enabled by the } \\
\text { Internet, DVDs, } \\
\text { games, etc. }\end{array}$ \\
\hline $\begin{array}{l}\text { The inclusion of } \\
\text { artworks in progress } \\
\text { within the film }\end{array}$ & & & \\
\hline
\end{tabular}

In recent times, most theories on cinematic realism have been concerned with the last category, that is, with realism as mode of reception. This has a history that I have addressed in detail in two books, World Cinema and the Ethics of Realism (2011) and Realism and the Audiovisual Media (2009), and will deserve a brief summary here. The emphasis on 
spectatorial reception emerged as a reaction against Cartesian traditions of body-mind dualism as seen in psychoanalytic approaches to film in the 1970s, in particular in French semiology and the Screen criticism, which famously defined the film spectator as a passive subject regressed to the Lacanian mirror-stage infancy. Most notably, cinematic realism was debunked as a "bourgeois genre" by critics such as Colin MacCabe, who compared it with the nineteenth-century realist novel on the basis of a narrative discourse which "allows reality to appear and denies its own status as articulation" (1974: 9). MacCabe then proceeded to place neorealism on an equal footing to Hollywood so as to reject both ([1976] 1986:180). Because of his defence of the former, Bazin was accused by MacCabe of rendering a "characterization of realism $[\ldots]$ centrally concerned with a transparency of form which is reduplicated within Hollywood filmic practice” ([1976] 1986: 180).

Most contentiously within the Screen criticism, but bearing uniquely foundational insights, Laura Mulvey’s essay "Visual Pleasure and Narrative Cinema” ([1975] 2009) condemned spectatorial pleasure as elicited by Hollywood cinema as narcissistic, scopophilic and ideologically charged. The reaction to these accusations came in the 1980s, when David Bordwell (1997), drawing on Constructivism, formulated theories around "mental structures" to explain the universal popularity of American mainstream cinema, while cognitivists such as Noël Carroll (1988) and Murray Smith (1996) rejected the Brecht-inspired opposition between illusionistic absorption and critical spectatorship. In the early 1990s, Deleuze's emphasis on sensory-motor modes of communication motivated critics such as Steven Shaviro (2006) to add the body to this equation, with a view to reinstating pleasure as constitutive of spectatorial experience. This was followed by the celebration of the "embodied spectator" in the 2000s, as most notably represented by Vivian Sobchack. Drawing on Merleau-Ponty's phenomenology, Sobchack proposed "embodiment" as "a radically material condition of the human being that necessarily entails both the body and 
consciousness, objectivity and subjectivity, in an irreducible ensemble" (2004: 4). Along the same lines, Laura Marks put forward the concept of "haptic criticism" as a kind of physical fusion between film and viewer (2002: xiii-xv).

As can be seen, the common thread across these views is the focus on realism as a reality effect on the human body and senses, hence on realism at the point of reception. It is indeed a fact that, regardless of their recording processes or modes of storytelling, audiovisual media can affect spectators by means of graphic representations able to cause physical and emotional impact even when there is no representational realism at play, for example, when the physical impact on the spectator derives from animation or computergenerated images and sounds (Black 2002). Traditional 2D screenings of action films are perfectly capable of producing reality effects, but particular modes of exhibition, such as 3D projections, Imax environments and the more recent 4D Virtual Reality devices, have been specifically designed to enhance them. With all of them, however, reality effects can only be effects and not actual reality, given the interdiction of spectatorial participation. Even Virtual Reality devices, though allowing the viewer to move their head freely and choose what to look or listen to within a $360^{\circ}$ spectrum, are unable to provide any kind of actual interaction. As Christian Metz was the first to note (1982: 61-65), there is an unbridgeable fracture between seeing and being seen in audiovisual media due to the temporal gap that separates the moment of shooting from that of viewing, and this is why, for Metz, the spectator's position at any film projection is necessarily scopophilic.

Reality effects are moreover subordinate to the varying subjective susceptibilities, hence impossible to measure by universal standards. There is also the fact that, as technology evolves and tricks are cracked, reality effects tend to wane with time and lose the battle against the human brain, which opposes a natural resistance to illusionism. A historical example is that of the audience members who purportedly fainted or ran away when first 
exposed to Lumière's Arrival of a Train at La Ciotat (L'Arrivée d'un train en gare de La Ciotat, 1895), a film which has become perfectly innocuous to current-day spectators. As Oliver Grau aptly explains:

When a new medium of illusion is introduced, it opens a gap between the power of the image's effect and conscious/reflected distancing in the observer. This gap narrows again with increasing exposure and there is a reversion to conscious appraisal. Habituation chips away at the illusion, and soon it no longer has the power to captivate. It becomes stale, and the audience are hardened to its attempts at illusion. At this stage, the observers are receptive to content and artistic media competence, until finally a new medium with even greater appeal to the senses and greater suggestive power comes along and casts a spell of illusion over the audience again. (2003: 152)

There is however one case in which objective realism can be found at the exhibition stage: when the film projection involves live performance. Expanded cinema experiments are the ultimate expression of this category, insofar as they preserve the auratic Einmaligkeit (or uniqueness) held by Benjamin as the very definition of an artwork. However, for this same reason, they also have to relent on the recording and replicating properties of the film medium aimed at reaching the masses - the "public" without which, as Bazin claims (1967c: 75), there is no cinema - as well as to the possibility of being preserved for posterity. Film studies tools alone are therefore insufficient to address such phenomena. 
As for modes of address, realism must forcibly be associated with the impression of reality elicited by what Baudry (1986) famously defined as the basic cinematographic apparatus (l'appareil de base), including the projector, the flat screen and the dark, collective auditorium. Despite film's vertiginous technological development since its invention and the multiplication of its uses, supports and platforms, the basic cinematographic apparatus as provided by the cinema auditorium has demonstrated extraordinary resilience, remaining for over a century the standard outlet for filmic experience. This endurance, I believe, is due to the comfort zone if affords the spectator between the reality effect and the natural brain resistance to total illusionism. It is moreover a space capable of accommodating a range of cinematic genres and styles, from classical narrative cinema of closure, devoted to eliciting an impression of reality, to mixed-genre productions endowed with disruptive devices that draw attention to the reality of the medium. Moreover, as Arnheim (1957: 3) had already noted, human 3D perception of reality is itself an illusion given that the human retina is as flat as the traditional cinema screen. The three-dimensional impression we have of objective reality is only produced thanks to our stereoscopic vision that promotes the fusion of two slightly different images resulting from the distance between our eyes.

This brings us back to the hypothesis announced at the beginning that the only clearly identifiable and measurable cinematic realism derives from the first category, that is, from modes of production, relying heavily on: the physical engagement on the part of crew and cast with the profilmic event; the near identity between the cast and their roles; real location shooting; the audiovisual medium's inherent indexical property; and the engagement with works of art in progress within the film. In films resulting from this mode of production, the illusionistic fictional thread (if existing) interweaves with documentary footage and/or approach, as well as with crew and cast's direct interference with the historical world, aimed not only at highlighting the reality of the medium but also at producing, as well as 
reproducing, social and historical reality. Needless to say, none of the modes above exist per se, a film relying on physical engagement at production point being only thus conceived for the specific reality effect it is expected to have on the spectator. Modes of production are however, I wish to argue, the only objective way of proofing and proving a film's intention, given the countless variables inflecting the ways in which films are subjectively perceived by each individual.

\section{Realism from Non-Cinema to the Myth of Total Cinema}

My first case study of realism as mode of production refers to a filmmaker who systematically refuses to abide by the rules of cinema in the name of a politics of the real: Jafar Panahi (see also Nagib 2016b in this respect). Any of Panahi's films could illustrate this hypothesis, but I will focus on This Is Not a Film (In film nist), shot in 2011, a title that already reflects an aversion to representational strategies. Confrontational and self-reflexive to the core, the film was made in defiance of the Iranian authorities, who had prohibited the director from making films and placed him under house arrest. With the complicity of assistant Mojtaba Mirtahmasb behind the camera, Panahi undertakes to secretly stage, inside his house, the difficulties of his current situation. But he dislikes the result and at a certain point decides to "remove his cast." The reference is to the nine-year-old Mina, the lead of one of his early films, The Mirror (Ayneh, 1997), who suddenly decides to abandon the shoot. She throws away the cast from around her arm, which was part of her character, changes into her normal clothes and sets out to find her way back home by herself on foot. The film then cuts to the section of The Mirror where this happens, which is shown on Panahi's TV set, after which the director confesses to his feeling that he had been pretending and lying in his own staging at home. Addressing Mirtahmasb behind the camera, he wonders whether this is 
a problem faced by all filmmakers, to which Mirtahmasb confirms that he is currently involved in a film entitled Behind the Scenes of Iranian Filmmakers Not Making Films, turning the self-denying effect of The Mirror into a specular mise-en-abyme.

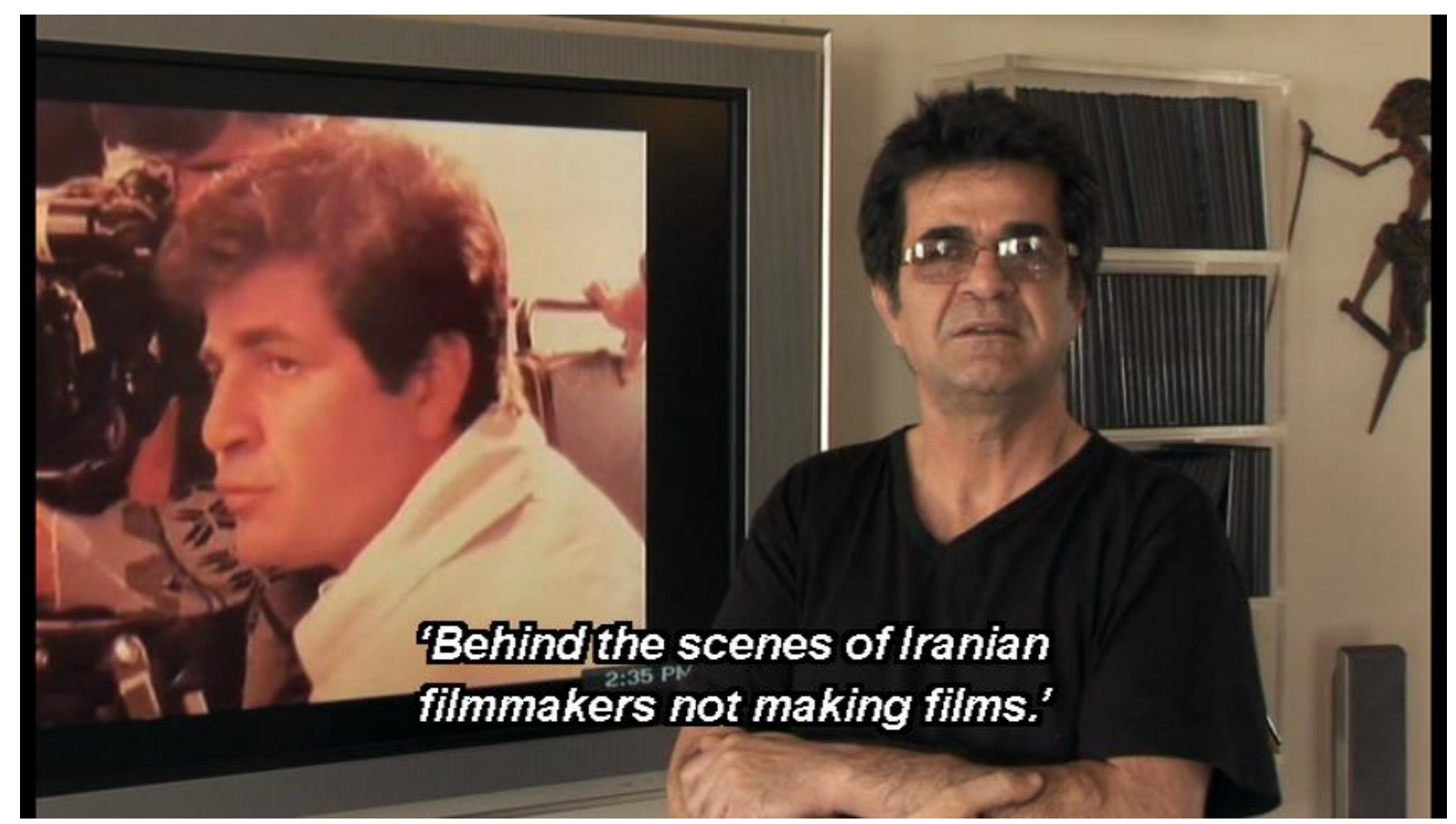

Figure 1. Cinematic self-negation mise-en-abyme: Jafar Panahi attempts to turn his film into real life (This is Not a Film, 2011).

The film The Mirror itself, made when Panahi was still relatively free as a filmmaker, demonstrates how his method had always been solidly anchored on a real that clashes against and ruins the possibility of a conventional film. For him, losing a character does not mean losing an actor, and accordingly he orders the crew to continue to shoot, profiting from the fact that Mina still has a functioning mic attached to her clothes. With the bus in which the team had been shooting they follow her as she braves Tehran's chaotic traffic in a similar way her character would probably have done in the fictional story. In pursuit of the girl on their bus, the crew often lose sight of her and, at times, also the signal of her mic. As a result, the film is a collection of "what is fortuitous, dirty, confused, unsteady, unclear, poorly framed, overexposed," as Lyotard had defined "acinema" (1986: 349), and the pure 
expression of the crew's fidelity to the unpredictable event of truth, in Badiou's definition of ethics. As for This Is Not a Film, now part of a trilogy including Closed Curtain (Pardé, 2013) and the Berlin Golden-Baer-winner Taxi Tehran (Taxi, 2015), all made in contravention of the filming ban imposed on Panahi, it ends literally with the "pyrotechnics" that Lyotard (1986: 351), citing Adorno, describes as the "only truly great art," as the director observes the fireworks celebrating the New Year from behind the gate of his building that he and his film cannot trespass. A self-consuming film is thus brought to light whose burning energy momentarily prevails over an oppressive regime.

My second case study provides material evidence to Bazin's (1967c) argument that realist is not only the cinema that straddles real life but also the one that merges with the other arts. The Brazilian film Delicate Crime (Crime delicado, Beto Brant, 2006) is a literary adaptation which changes consecutively into theatre and painting, without recognizing frontiers between these different mediums. One of the film's narrative strands focuses on Inês, a young woman who has a disability both in the film and in real life: she lacks a leg. Inês models for a painter, José Torres Campana, played by Mexican diplomat Felipe Ehrenberg, who is also a painter in real life. At a certain point, Inês is shown posing for the film's key work, called "Pas de deux." Painter and model are naked and engaged in different embraces during which he draws the sketches which are subsequently transferred to the canvas. Both processes (the drawing of the sketches and the actual painting) are shot while in progress, that is, Ehrenberg produced this painting during the actual shooting of the film. Thus, what we see in this scene is the actors leaping out of representation and into a presentational regime in which the production of an artwork is concomitant with its reproduction. 
Figure 1. Cinematic self-negation mise-en-abyme: Jafar Panahi attempts to turn his film into real life (This is Not a Film, 2011).

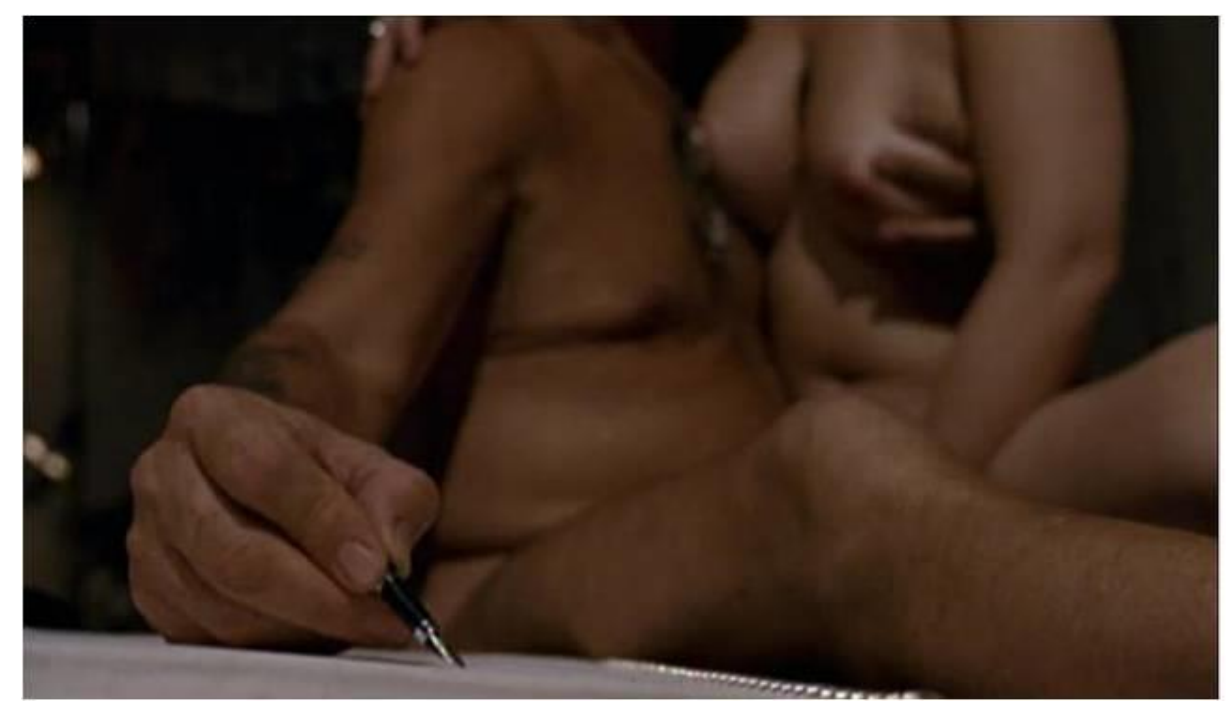

Figure 2. Sexual embraces turn into drawing and painting, establishing an indelible link between living and representing reality (Delicate Crime, 2006).

Indeed, the most startling aspect of the scene of the painting of "Pas de deux" is that a real painter and a real model agreed to create an artwork in real life while simultaneously playing fictional characters in a film. The fact that this involved full nudity and physical intimacy between both, and that, to that end, the model, who is disabled in real life, had to remove her prosthetic leg before the camera, indicates the transformative effect the film necessarily had on the actors' actual lives (as became known, the actress Lilian Taublib never wore her prosthetic leg again after the film). The resulting picture has in its centre an erect penis placed next to a dilated vulva, implying that if the painting was real, so was also the sexual arousal between painter and model. Suggestively, the male organ appears as substitute of the missing leg, filling in the representational gap that allows for art (and sex) to become reality.

To complete my analysis, I will now address an impulse pointing in the opposite direction to non-cinema, which is total cinema. In lieu of a cinema which, in order to acquire the status of art and political power, dissolves itself into real live or the other arts, total 
cinema is the one which aspires to change life itself into film. Our world is becoming increasingly captive to the power of speed and the cut, as represented by the typical Facebook super-short films, made for the minuscule screens of mobile phones or even wristwatches. However, the films I am addressing here under the name of "total cinema" place all their bets on duration and the giant screen, as an unflinching commitment to the film medium as we used to know it. Instead of the constant distraction of the Internet, this cinema proposes immersion in the traditional sense of the "basic cinematographic apparatus," according to Braudry's famous formula, which includes the collective audience, the dark room, the projector and the large screen, as well as the long duration, which together produce an illusion of reality analogous to that produced in Plato's cave. In formulating his concept of “total cinema," Bazin (1967d) was most certainly inspired by René Barjavel, whose futuristic book-length essay Cinéma total: essai sur les formes futures du Cinéma, written in 1944, has only recently returned to the debate. Barjavel's enormously insightful take on cinema's relentless search for realism through technological development predicted the collapsing of all arts into cinema in the following terms: "Total cinema will not replace the traditional arts. It will give them a new vigour, feeding them with the blood donated by the masses" (1944: 39). Such an assertion curiously chimes with Jens Schröter (2010: 113), who ascribes the yearning for the fusion between art and life to the same "genealogical line" of Wagner's total work of art. For Bazin, however, total cinema is a "myth" insofar as its unattainable utopia is "integral realism," that is, the perfect identity between cinema and real life (1967d: 21). As a result, and in tune with his aversion to illusionism as produced by montage cinema, spectatorial engagement in total cinema would be the act of actually and materially inhabiting it. Bazin goes even further by describing, a propos of total cinema, a desire to achieve a "complete imitation of nature" (21), and indeed the notion of "nature" is key to the films in question here, whose totalizing endeavour expresses itself in the form of monumental 
landscapes and the emphasis on the long shot, as opposed to the fragmentation of the closeup.

An important section of world cinema over the last decade has been prone to the landscape film, more specifically as regards threatened landscapes. Examples abound from all over the world, with the likes of Carlos Reygadas in Mexico, Lisandro Alonso in Argentina, Jia Zhangke in China, Lav Diaz in the Philippines, Andrey Zvyagintsev in Russia, Nuri Bilge Çeylan in Turkey, Abderrahmane Sissako in Mali and many others. Although all of them make full use of digital technology, their films are marked by an obsessive preoccupation with production rather than post-production, that is, with capturing objects within a wider whole, with an indexicality which establishes a material link between the film and its historical and geographical context. These films stand therefore in direct opposition to mobile-phone super-short film fragments, which are an endless exercise in decontextualization.

Paradoxically, however, it is the unavoidable human figure, behind and before the camera, the greatest threat to this cinema. Simon Schama states that "nature may exist without us [...] it doesn’t need us, whereas landscape requires some degree of human presence and affect" (cited in Lefebvre 2011: 70). Thus, the first obstacle to the realization of total cinema is that its images are not anymore the "nature" which Bazin refers to, but simply landscapes, framed and limited by the human eye. The second obstacle refers to cinema's own temporality which, in contrast to static arts such as photography and painting, necessarily adds to any landscape an evanescent character. Take, for example, the opening of Leviathan (Leviafan, Andrey Zvyagintsev, 2014). A series of shots of monumental cliffs on the seashore slowly unveils the human presence, indicated by electric towers, winding roads and derelict fishing boats at the port. Eventually, a house and one of its inhabitants are presented to the camera, now duly contextualized within the landscape and in conflict with it, 
for it changes it into a suburban setting carrying the sign of death (the end of an autonomous fishing tradition replaced by industrial mass fishing and processing). Total cinema here is defined as the mutual exclusion between human being and nature resulting in the evanescent landscape and hinting at the excessive character of the object total cinema craves for without ever managing to capture in its entirety.

Kant (1960) distinguishes between the "beautiful" and the "sublime," noting that the former refers to the object's form and is limited, whereas the latter derives from a formless, unlimited object. For Kant, human sensibility and imagination are insufficient to fully comprehend phenomena happening in the realm of the sublime. This assessment curiously resonates with Bazin's total-cinema idea as read by Tom Gunning, who states that "a myth always exceeds a concept, and Bazin's essay examines one of the traditional tasks of myth, a tale of origin" (2011: 120). Indeed, there is a clear supra-rational and inexplicable element in the cinematic landscapes in question here, signalling, not at a divine or supernatural presence, but simply at the materiality of death, as in the magnificent image, in Leviathan, where a whale's gigantic skeleton confronts a child criminal, its disproportionate dimensions in comparison with the minute human subject still insufficient to prevail over the latter's destructive will and power.

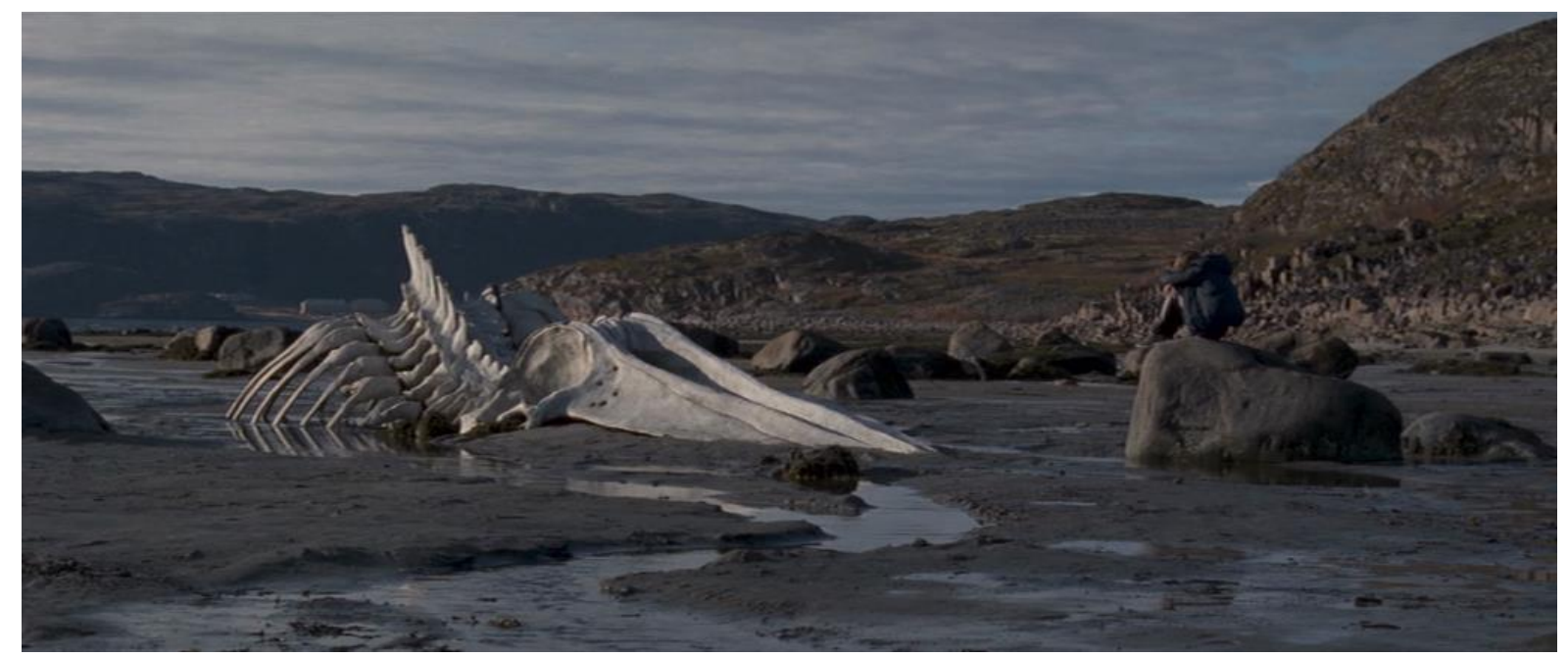

Figure 3. The human presence presents a death threat to real landscapes, shattering the myth of "integral realism" (Leviathan, 2014). 
The films I am referring to as adept of the "myth of total cinema" are actually political in the strongest sense, animated as they are by questions such as tourism invasion, in Cyelan's Winter Sleep (Kiş uykusu, 2014), the spread of fundamentalist terrorism as represented by Al Qaeda and the Islamic State in Sissako's Timbuktu (2014), property expansion in Leviathan, or the flooding of millions of homes for the construction of the Three Gorges Dam in Jia's Still Life (Sānxiá hăorén, 2006). In the latter film, as Cecília Mello (2014) has beautifully analyzed, the Three Gorges landscape, printed as a national symbol on a 10 Yuan bill, is reduced to a miniature of itself when framed by the monetary power symbolically held by the hand of a construction worker who unwittingly contributes to its end.

In his neorealist manifesto, "Cinema Antropomorfico" (Anthropomorphic Cinema), Luchino Visconti ([1943] 1996: 102) states: "I could make a film of a wall, if I knew how to retrieve the traces of true humanity of the men standing in front of this bare prop: retrieve them and retell them." This humanity Visconti is referring to is what makes total cinema at once necessary and impossible, restricted as it is by its own humanist realism. But it is here, in the face of the human limits imposed on integral realism, that total cinema meets noncinema, and world cinema becomes simply realist cinema: a mode of production and a way of life.

\section{Bibliography}

Arnheim, R. (1957) Film as Art, Berkeley/Los Angeles/London: University of California Press.

Badiou, A. (2006) Being and Event, translated by Oliver Feltham. London/New York: Continuum.

Barjavel, R. (1944) Cinéma total: essai sur les formes futures du Cinéma, Paris: Denoël. 
Baudry, J-L. (1986) "Ideological Effects of the Basic Cinematographic Apparatus," in Rosen, P. (ed.) Narrative, Apparatus, Ideology, New York: Columbia University Press, pp. 286-298.

Bazin, A. (1967) “The Ontology of the Photographic Image," in What Is Cinema? Vol. 1, essays selected and translated by Hugh Gray. Berkeley/Los Angeles/London: University of California Press, pp. 9-16.

Bazin, A. (1967b) "The Evolution of the Language of Cinema," in What Is Cinema? Vol. 1, essays selected and translated by Hugh Gray. Berkeley/Los Angeles/London: University of California Press, pp. 23-40.

Bazin, A. (1967c) "In Defence of Mixed Cinema," in What Is Cinema? Vol. 1, essays selected and translated by Hugh Gray. Berkeley/Los Angeles/London: University of California Press, pp. 53-75.

Bazin, A. (1967d) "The Myth of Total Cinema," in What Is Cinema? Vol. 1, essays selected and translated by Hugh Gray. Berkeley/Los Angeles/London: University of California Press, pp. 17-22.

Black, J. (2002) The Reality Effect: Film Culture and the Graphic Imperative, New York: Routledge.

Bordwell, D. (1997) Narration in the Fiction Film, London: Routledge.

Deleuze, G. (2013) Cinema II: The Time-Image, translated by Hugh Tomlinson and Robert Galeta. London/New Delhi/New York/Sydney: Bloomsbury. 
Denson, S. and Leyda, J. (eds) (2016) Post-Cinema: Theorizing $21^{\text {st }}$-Century Film, REFRAME Books: http://reframe.sussex.ac.uk/post-cinema (accessed 21 February 2017).

Elsaesser, T. (2009) “World Cinema: Realism, Evidence, Presence,” in Nagib, L. and Mello, C (eds) Realism and the Audiovisual Media, Basingstoke: Palgrave, pp. 3-19.

Gunning, T. (2011) “The World in Its Own Image: The Myth of Total Cinema,” in Andrew, D. and Joubert-Laurencin, H. Opening Bazin: Postwar Film Theory \& Its Afterlife, Oxford/New York: Oxford University Press, pp. 119-126.

Grau, O. (2003) Virtual Art: From Illusion to Immersion, Cambridge, MA/London: MIT Press.

Hansen, M.B. (1997) "Introduction," in Kracauer, S. (1997) Theory of Film: The Redemption of Physical Reality. Princeton: Princeton University Press, pp. vii-xlv.

Kant, I. (1960) Observations on the Feeling of the Beautiful and Sublime, translated by John T. Goldthwait. Berkeley/Los Angeles/London: University of California Press.

Kracauer, S. (1997) Theory of Film: The Redemption of Physical Reality. Princeton: Princeton University Press.

Lyotard, J.F. (1986) “Acinema," in Rosen, P. (ed.) Narrative, Apparatus, Ideology, New York: Columbia University Press, pp. 349-59.

Lefebvre, M. (2011) “On Landscape in Narrative Cinema," Canadian Journal of Film Studies, vol. 20, n. 1, Spring, pp. 61-78.

MacCabe, C. (1974) "Realism and the Cinema: Notes on Some Brechtian Theses," Screen, 15 (2), Summer, pp. 7-27. 
MacCabe, C. (1986) "Theory and Film: Principles of Realism and Pleasure," in Rosen, P. (ed.) Narrative, Apparatus, Ideology, New York: Columbia University Press, pp. 179197.

Manovich, L. (2016) “What Is Digital Cinema?,” in Denson, S. and Leyda, J. (2016) (eds) Post-Cinema: Theorizing $21^{\text {st }}$-Century Film, REFRAME Books: http://reframe.sussex.ac.uk/post-cinema (accessed 21 February 2017), pp. 20-50.

Marks, L. U. (2002) Touch: Sensuous Theory and Multisensory Media, Minneapolis/London: University of Minnesota Press.

Martin-Jones, D. (2011) Deleuze and World Cinemas, London/New York: Continuum.

Mello, C. (2014) “Space and Intermediality in Jia Zhang-ke's Still Life,” Aniki, vol. 1, n. 2, pp. 274-291.

Metz, C. (1982) The Imaginary Signifier: Psychoanalysis and the Cinema, translated by Celia Britton, Annwyl Williams, Ben Brewster and Alfred Guzzetti. Bloomington/Indianapolis: Indiana University Press.

Mulvey, L. "Visual Pleasure and Narrative Cinema," in Visual and Other Pleasures, $2^{\text {nd }}$ edition, Basingstoke: Palgrave, pp. 14-30.

Nagib, L. (2006) “Towards a Positive Definition of World Cinema," in Dennison, S. and Lim, S.H. (eds) Remapping World Cinema: Identity, Culture and Politics in Film, London: Wallflower Press, pp. 30-37.

Nagib, L. and Mello, C. (eds) (2009) Realism and the Audiovisual Media, Basingstoke: Palgrave.

Nagib, L. (2011) World Cinema and the Ethics of Realism, New York/London: Continuum. 
Nagib, L., Perriam, C. and Dudrah, R. (eds) (2012) Theorizing World Cinema, London/New York: I.B. Tauris.

Nagib, L. (2016) "The politics of slowness and the traps of modernity," in De Luca, T. and Barradas Jorge, N. (eds) Slow Cinema, Edinburgh: Edinburgh University Press, pp. 25-46.

Nagib, L. (2016b) "Non-cinema, or the location of politics in film," Film-Philosophy, 20 (1). pp. 131-148.

Schröter, J. (2010) “The Politics of Intermediality," Film and Media Studies, 2, pp. 107-124.

Shaviro, S. (2006) The Cinematic Body, Minneapolis/London: University of Minnesota Press.

Sobchack, V. (2004) Carnal Thoughts: Embodiment and Moving Image Culture, Berkeley/Los Angeles/London: University of California Press.

Stone, R. (2015) “About Time: Before Boyhood,” Film Quarterly, vol. 68, n. 3, Spring, pp. $67-72$.

Visconti, L. (1996) “Cinema Antropomorfico,” in Micciché, L. Luchino Visconti: Un profilo critico. Venice: Marsilio, pp. 100-102. Originally published in Cinema, VIII, n. 1734, 25/09-25/10/1943, pp. 108-109.

Wollen, P. (1998) Signs and Meaning in the Cinema, London: BFI. 